\title{
Triticale silage treated or not with homolactic acid bacteria ensiled in laboratory mini-silos ${ }^{1,2}$
}

\author{
Luis C. Solórzano ${ }^{3}$, Luis L. Solórzano 4 \\ and Abner Rodríguez-Carias ${ }^{5}$
}

J. Agric. Univ. P.R. 100(2):183-201 (2016)

\begin{abstract}
In two experiments, we studied the characteristics of ensiling and aerobic stability of triticale (x Triticosecale spp.) ensiled with or without a homolactic bacterial inoculant (HBI). The first experiment used 60 vacuumsealed $0.946 \mathrm{~L}$ glass jar mini-silos (GJ) to determine the effect of ensiling on $\mathrm{pH}$, dry matter recovery (DMR) and temperature. Three GJ per treatment were opened on d $0,1,2,3,5,7,14,30,105$ and 123 of fermentation. Across all lengths of fermentation, inoculation decreased $(P<0.05)$ average silage $\mathrm{pH}$ and temperature upon opening the mini-silos but did not influence $(P>0.05)$ DMR versus the Non-HBI silage. Both silages had a similar $(P>0.05)$ $\mathrm{pH}$ at the end of $123 \mathrm{~d}$ of fermentation. The second experiment compared the nutritional and fermentation characteristics and aerobic stability of triticale ensiled with or without $\mathrm{HBI}$ for $123 \mathrm{~d}$ in either 3.L PVC mini-silos packed manually (PVC) or vacuum-sealed GJ. There was little difference $(P>0.05)$ in silage nutrient content using PVC or GJ mini-silos, nor did inoculation affect these variables. Ensiling triticale decreased $(P<0.05)$ its $30 \mathrm{~h}$ neutral detergent fiber (NDF) digestibility, the lowest value being that of Non-HBI/ PVC silage, which differed $(P<0.05)$ from the HBI/PVC silage, but these did not differ $(P>0.05)$ from the GJ silages. Differences among silages were not found ( $P>0.05$ ) in NDF at $240 \mathrm{~h}$ (UNDF240), total tract NDF digestion (TTNDFD) and rate of NDF digestion $\left(\mathrm{NDF}_{\mathrm{kd}}\right)$. Triticale ensiled well in GJ, however the amount of material ensiled may have been too small to detect differences due to inoculation.
\end{abstract}

Key words: triticale, silage, re-ensiling, bacterial inoculation, fermentation

\section{RESUMEN}

Evaluación de ensilaje de triticale inoculado con bacterias homolácticas en minisilos de laboratorio

En el primero de dos experimentos se determinó el efecto sobre el pH, la recuperación de materia seca (RMS) y la temperatura de ensilar triticale

${ }^{1}$ Manuscript submitted to Editorial Board 25 August 2016.

${ }^{2}$ The authors wish to express their gratitude to Anabel Rodríguez for her assistance in translating the document.

${ }^{3}$ Adjunct Professor, Animal Science Department, Univ. of Puerto Rico, Mayagüez

Campus, PO Box 9000, Mayagüez, PR 00680. E-mail: luis.solorzano1@upr.edu.

${ }^{4}$ Independent Researcher, 5839 Devoro Rd., Fitchburg, WI 5371

${ }^{5}$ Professor, Animal Science Department, Univ. of Puerto Rico, Mayagüez Campus. 
(x Triticosecale spp.) con o sin inoculante de bacteria homoláctica (IBH), utilizando 30 minisilos de vidrio de $0.946 \mathrm{~L}$ sellados al vacío (GJ) por tratamiento, que se abrieron a los días $0,1,2,3,5,7,14,30,105$ y 123 de fermentación. Abarcando todos los largos de fermentación, la inoculación redujo $(\mathrm{P}<0.05)$ las medias de $\mathrm{pH}$ y temperatura al abrir los minisilos, pero no influyó $(P>0.05)$ en la RMS relativo al ensilaje sin IBH. Ambos ensilajes tuvieron un $\mathrm{pH}$ similar $(P>0.05)$ al finalizar el periodo de fermentación de $123 \mathrm{~d}$. En el segundo experimento se compararon las características nutricionales, la fermentación y la estabilidad aeróbica del triticale ensilado con o sin IBH durante 123 d en minisilos de 3. L hechos de PVC y empacados manualmente o de GJ y sellados al vacío. Hubo mínimas diferencias $(P>0.05)$ en el contenido nutricional del ensilaje fermentado en minisilos de PVC OGJ y la inoculación tampoco afectó estas variables. El ensilamiento de triticale disminuyó $(P<0.05)$ la digestibilidad de la fibra detergente neutro (FDN) a las $30 \mathrm{~h}$, correspondiendo el menor valor al ensilaje sin IBH/PVC, que difírió $(P<0.05)$ del ensilaje IBH/PVC, pero estos no tuvieron diferencia $(P>0.05)$ con los ensilados en GJ. No hubo diferencia entre los ensilajes $(P>0.05)$ en FDN no degradable a las $240 \mathrm{~h}$ (UFDN240), digestibilidad de FDN en el tracto entero (TTNDFD) y la velocidad de digestión de la FDN (FDN ${ }_{k d}$ ). EI triticale fermentó bien en los minisilos de vidrio, sin embargo, la cantidad de material ensilado puede que no haya sido suficiente para poder detectar diferencias debido a la inoculación.

Palabras clave: triticale, ensilaje, reensilamiento, inoculación bacteriana, fermentación

\section{INTRODUCTION}

The goal of ensiling is primarily to convert water-soluble plant sugars to lactic acid in an anaerobic fermentation. When sufficient lactic acid has accumulated, all microbial activity is suppressed and the silage can then be stored anaerobically until required for feeding (Rooke and Hatfield, 2003). Muck (1988) described four variables that adversely affect the ensiling process: 1) plant respiration; 2) plant enzyme activity; 3) clostridial activity; and 4) aerobic microbial activity. It is next to impossible to control these variables repeatedly in farm-sized silos. If silage fermentation is to be studied and understood, then there is a need for research using laboratory-size silos that allow control of said variables and permit the assessment of different experimental treatments. Entire contents of laboratory silos can be weighed, processed and analyzed accurately (Cherney et al., 2004). Also, laboratory silos allow for replication to estimate the variability associated with each treatment. In the past, mini-silos of different types and sizes have been used (Xiccato et al., 1994; Colovic et al., 2010) in the quest for an alternative that is cost effective, requires a small sample size, reduces labor and increases repeatability. Xiccato et al. (1994) concluded that $500 \mathrm{~L}$ and $2 \mathrm{~L}$ experimental silos are useful devices to study the conservation of ensiled forage because they faithfully reflect the process that normally occurs in farm bunker silos. Most laboratory silos require man- 
ual packing, which introduces a variable that may affect the results of an experiment, since packing density lacks uniformity. Cherney et al. (2004) concluded that it is possible to use vacuum-sealed plastic bags to ensile corn, with samples as small as $200 \mathrm{~g}$, to assess treatment differences when it is not practical to evaluate all treatments using commercial silos. Vacuum packing permits higher throughput during silo packing and the consistency of initial packing density is more uniform and much less susceptible to operator differences, particularly when more heterogeneous substrates are ensiled (Johnson et al., 2005). The current research consisted of two experiments. The first studied the effects on $\mathrm{pH}$, dry matter recovery (DMR) and the temperature of triticale ( $\mathrm{x}$ Triticosecale spp.) ensiled with or without a homolactic bacterial inoculant (HBI), over a $123 \mathrm{~d}$ fermentation period, in vacuum-sealed glass jar mini-silos (GJ). The second experiment compared the nutritional and fermentation characteristics and aerobic stability of triticale ensiled with or without HBI for $123 \mathrm{~d}$ in either $3 \mathrm{~L}$ PVC (PVC) mini-silos manually packed or 0.946 L GJ vacuum-sealed.

\section{MATERIALS AND METHODS}

\section{Vegetative material}

The same vegetative material was used for both experiments, which were conducted concurrently. Triticale was grown at a commercial crop farm in Lafayette County, WI. Whole plant triticale was cut, swathed and allowed to wilt to a moisture content of approximately $65 \%$. Wilted triticale was chopped to a theoretical length of cut (TLC) of $20 \mathrm{~mm}$ and transported to Fitchburg, WI, for further processing. Particle size distribution as determined using the Penn State particle size separator (Heinrichs and Kononoff, 1996) was as follows: 23.9, 43.2 and 31\% of the sample remained on top of the sieves with a pore size of 19.04, 7.85 and $1.27 \mathrm{~mm}$, respectively; and $2 \%$ reached the bottom pan. This particle size distribution of the chopped triticale was favorable according to the recommendation provided by Heinrichs and Kononoff (1996) for haylage. One-half of the vegetative material was inoculated using a water soluble HBI at a rate of $1.1 \mathrm{~g} / \mathrm{t}$ of wilted matter with a product supplying $>9.1 \times 10^{10} \mathrm{CFU} / \mathrm{g}$ and containing Pediococcus acidilactici, $P$. pentosacesus, Lactobacillus plantarum and Lactococcus lactis $(\mathrm{Nu}-$ Realm, LLC, Hutisford, WI ${ }^{6}$. The other half of the vegetative material

\footnotetext{
${ }^{6}$ Company or trade names in this publication are used only to provide specific information. Mention of a company or trade name does not constitute an endorsement by the Agricultural Experiment Station of the University of Puerto Rico, nor is this mention a statement of preference over other equipment or materials.
} 
received the same amount of water. The liquids were applied using a hand sprayer while the forage was mixed manually. Four samples each of wilted and inoculated herbage were collected prior to ensiling and stored at $-18^{\circ} \mathrm{C}$ until analyzed. These samples corresponded to $\mathrm{d} 0$ of fermentation for purposes of statistical analysis.

\section{Experiment \# 1}

\section{Fermentation process and dry matter recovery}

Sixty GJ mini-silos of $0.946 \mathrm{~L}$ capacity were filled with about $300 \mathrm{~g}$ of the crop at about $35 \%$ dry matter (DM) and $5.2 \%$ soluble carbohydrates (DM basis). One-half of the silos were filled with the Non-HBI vegetative material and the other half with the HBI material; the mini-silos were vacuum-sealed using a Food Saver FM2001 (Sunbeam Corp., Boca Raton, FL, USA 33431) with a wide mouth jar adaptor. Triticale was fermented at a temperature of 20 to $23^{\circ} \mathrm{C}$. Glass jar mini-silos were opened on d $0,1,2,3,5,7,14,30,105$ and 123 of fermentation. Upon opening, silages were analyzed for DM by microwave oven drying until reaching a constant weight; $\mathrm{pH}$ and temperature were recorded and DMR was calculated from the silage dry matter recovered at silo opening divided by the dry matter mass ensiled, multiplied by 100 . For $\mathrm{pH}$ determination, a $20 \mathrm{~g}$ subsample was collected, diluted 10 -fold on a mass basis with distilled water, and macerated for $60 \mathrm{~s}$ in a high-speed blender. The extract was filtered through four layers of cheesecloth, and $\mathrm{pH}$ was measured immediately with a pH meter (Measure Up model PH-2011, Etekcity, Anaheim, CA, USA). Temperature was determined using a 12-cm Taylor thermometer (model 5989) placed in the middle of each GJ. Data for DM, $\mathrm{pH}$, temperature and DMR were analyzed using the GLM of SAS (SAS Institute, 2004) in a completely randomized design (CRD) replicated four times with a factorial arrangement of treatments composed of two levels of inoculation (inoculated or not) and 10 lengths of fermentation. Tukey's test was used for mean separation.

\section{Experiment \# 2}

\section{Fermentation process}

Eight 3 L capacity PVC mini-silos fitted with two-way mechanics to vent gas were filled with about $2 \mathrm{~kg}$ of the crop at about $35 \%$ DM and $5.2 \%$ soluble carbohydrates (DM basis). Additionally, six GJ mini-silos with a capacity of $0.946 \mathrm{~L}$ were filled with the same crop and vacuum-sealed as in Experiment \# 1 (Figure 1). Four PVC and three GJ mini-silos were assigned to each treatment to be evaluated: 1) No HBI in PVC mini-silo (Non-HBI/PVC); 2) HBI in PVC mini-silo (HBI/PVC); 3) No HBI in GJ mini-silo (Non-HBI/GJ); 4) HBI in GJ 


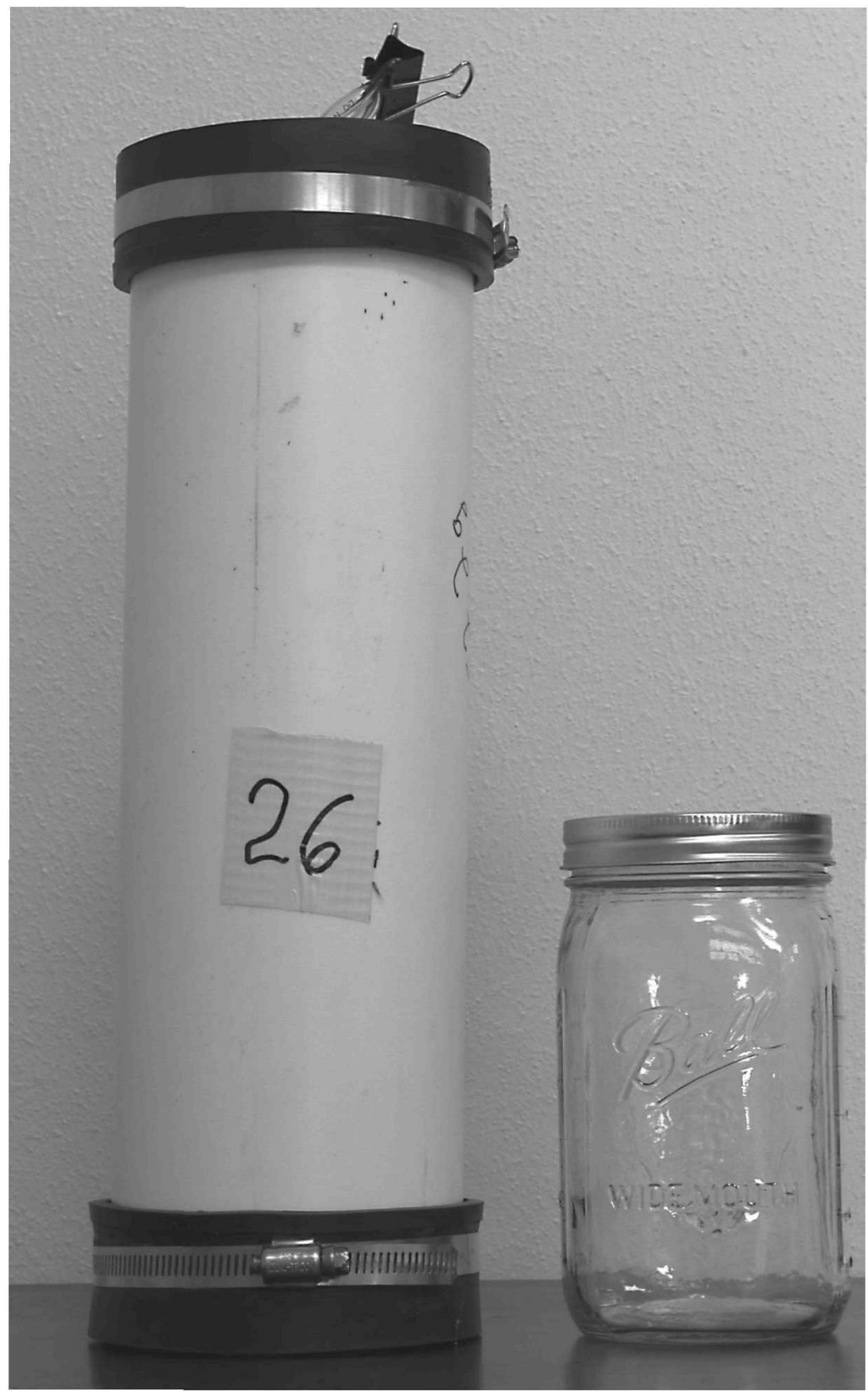

FIGURE 1. PVC and glass mini-silos used in Experiment \#2. 
mini-silo (HBI/GJ). Triticale was fermented for $120 \mathrm{~d}$ at 20 to $23^{\circ} \mathrm{C}$. Upon opening the mini-silos, silages were weighed, their temperature measured and samples taken for subsequent analysis for nutrient content and fermentation products. Samples of pre-ensiled forage and silages were analyzed for DM, crude protein (CP), acid detergent fiber (ADF), amylase treated NDF (aNDF), ether extract (EE), ash, acid detergent insoluble crude protein (ADICP), lignin, starch, water soluble carbohydrates (WSC), non-fibrous carbohydrates (NFC) and NDF digestion characteristics (Rock River Laboratory, Inc. Watertown, WI; NIRS technique). At the same laboratory, fermentation characteristics ( $\mathrm{pH}$; lactic, acetic, propionic, and butyric acids; ethanol; total volatile fatty acids (VFA); and ammonia nitrogen $\left(\mathrm{NH}_{3}-\mathrm{N}\right)$ were analyzed by wet chemistry. DMR was calculated from the silage DM recovered at silo opening divided by the DM mass ensiled, multiplied by 100 .

Data for nutrient content and fermentation characteristics were analyzed using the GLM of SAS (SAS Institute, 2004) in a CRD replicated four times with 6 treatments ( 2 wilted forages and 4 silages). Silage temperature at opening and DMR were analyzed in a CRD replicated four times with four treatments (silages only). Tukey's test was used for mean separation.

Aerobic stability

Aerobic stability was determined in the resulting silages by monitoring temperature at $6 \mathrm{~h}$ intervals during $7 \mathrm{~d}$ (Honig, 1986). Approximately $300 \mathrm{~g}$ of each silage was loosely placed in Styrofoam containers, which were then placed in thermally insulated chambers and exposed to air. A 12-cm Taylor thermometer (model 5989) was placed in the middle of each sample. Aerobic stability was defined as the time after opening for silage temperature to reach $3^{\circ} \mathrm{C}$ above ambient. Data analysis employed the GLM of SAS (SAS Institute, 2004) as a split plot design replicated four times with a factorial arrangement of four treatments $\times 29$ time points when temperature was recorded.

\section{RESULTS AND DISCUSSION}

\section{Experiment \# 1}

According to values averaged across the 10 different lengths of fermentation, inoculation decreased $(\mathrm{P}<0.05)$ silage $\mathrm{pH}$ and the temperature upon opening the mini-silos but did not influence $(P>0.05)$ DMR (Table 1) compared with the Non-HBI silage. Significant interactions $(\mathrm{P}<0.05)$ of treatment $\mathrm{x}$ length of fermentation were found for $\mathrm{pH}$ 
TABLE 1.-Mean $p H$, dry matter recovery and silage temperature across 10 time points of fermentation for triticale silage stored in glass jar mini-silos.

\begin{tabular}{|c|c|c|c|c|}
\hline \multirow[b]{2}{*}{ Item } & \multicolumn{2}{|c|}{ Treatment } & \multirow[b]{2}{*}{$\mathrm{SD}$} & \multirow[b]{2}{*}{$\mathrm{P}<$} \\
\hline & Non-HBI ${ }^{1}$ & HBI & & \\
\hline $\mathrm{pH}$ & $5.21 \mathrm{a}^{2}$ & $4.98 \mathrm{~b}$ & 0.17 & 0.0001 \\
\hline Temperature upon opening mini-silos, ${ }^{\circ} \mathrm{C}$ & $21.7 \mathrm{a}$ & $21.1 \mathrm{~b}$ & 0.43 & 0.001 \\
\hline Dry matter recovery, $\%$ & 89.88 & 89.76 & 3.25 & 0.89 \\
\hline
\end{tabular}

${ }^{1}$ Homolactic bacterial inoculant (HBI)

${ }^{2}$ Within a row, means with different letters differ $\mathrm{P}<0.05$

(Figure 2) and temperature of the silage (Figure 3), but not for DMR (Figure 4) at the opening of the mini-silo. The $\mathrm{pH}$ for the HBI silage decreased $(\mathrm{P}<0.05)$ rapidly until $\mathrm{d} 3$ of fermentation and then began to rise slowly while that of the Non-HBI silage continued to decrease until $\mathrm{d} 5$ of fermentation and then it remained relatively stable. These results are not in accordance with the statement by Muck (1988) that a homo-fermentative condition will not substantially speed

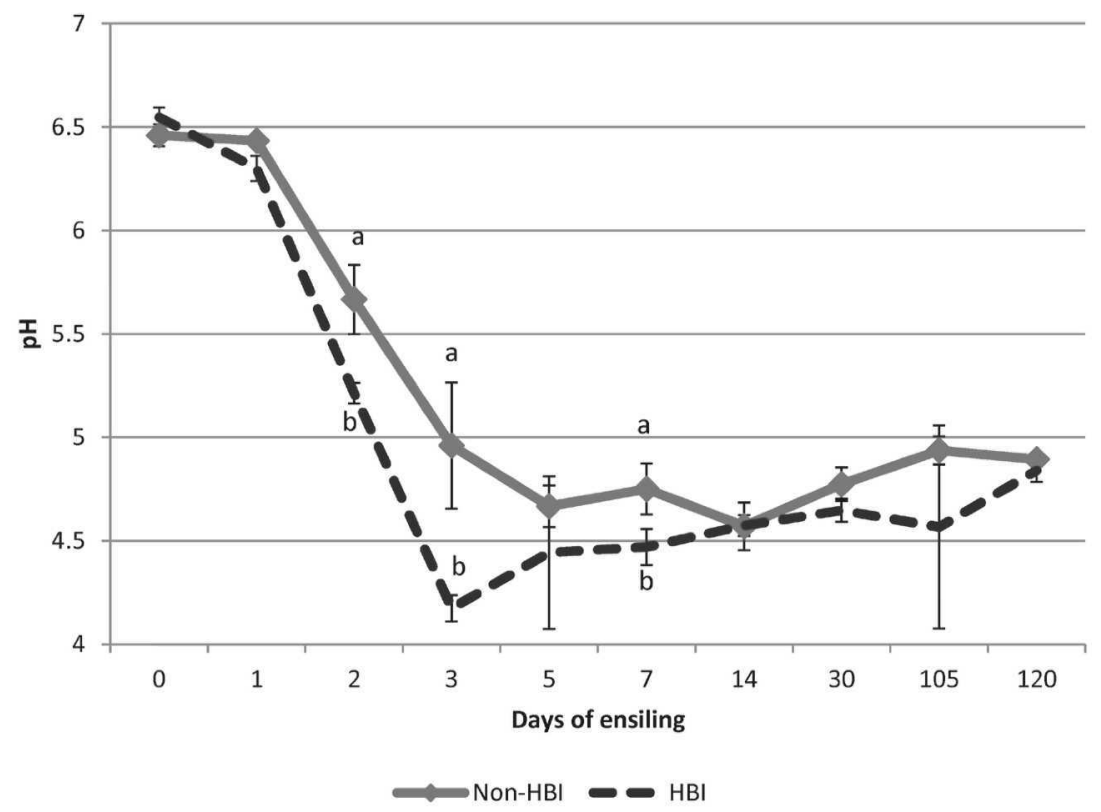

Figure 2. Effect of inoculation or not on the $\mathrm{pH}$ of triticale ensiled in glass jar minisilos during $123 \mathrm{~d}$ in Experiment \#1. Interaction of treatment $\mathrm{x}$ day of fermentation $\mathrm{P}<0.004$. 


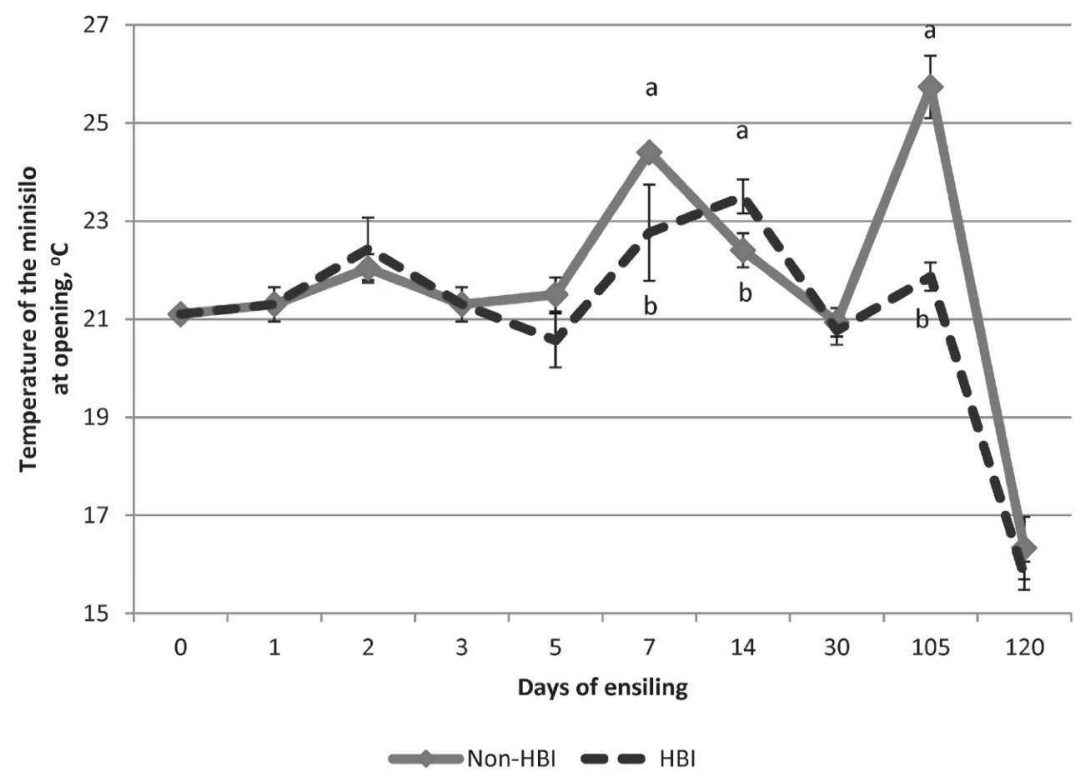

FIGURE 3. Effect of inoculation or not on the temperature of triticale ensiled in glass jar mini-silos during $123 \mathrm{~d}$ in Experiment \#1. Interaction of treatment $\mathrm{x}$ day of fermentation $\mathrm{P}<0.0001$.

the initiation of $\mathrm{pH}$ decline even though a lower final $\mathrm{pH}$ would be expected. Rather the present results show that inoculation decreased $\mathrm{pH}$ early in the fermentation, but at the end of $123 \mathrm{~d}$, no differences between treatments remained (Figure 2). This type of result is often witnessed in horizontal silos at the farm level as well. Johnson et al. (2005) determined that the rate of $\mathrm{pH}$ decline for ensiled perennial ryegrass was significantly affected by packing density in vacuum-sealed mini-silos, with the greatest divergence detected at 4 and $7 \mathrm{~d}$ post-ensiling. However, by $16 \mathrm{~d}$ there was no significant $\mathrm{pH}$ difference among different packing densities. Individual mini-silo packing density was not determined in the present study, but any differences are deemed likely to have little influence on the results. The most common effect of inoculants is an accelerated post-ensiling decline in $\mathrm{pH}$. However, McAllister and Hristov (2000) found that after $50 \mathrm{~d}$ of fermentation the differences in $\mathrm{pH}$ between inoculated and non-inoculated barley silage were small. The behavior in $\mathrm{pH}$ decline observed by Johnson et al. (2005) and McAllister and Hristov (2000) are similar to that observed in the present study. The Non-HBI silage never reached a $\mathrm{pH}$ as low as the minimum observed in the HBI silage. Muck (1988) indicated that 


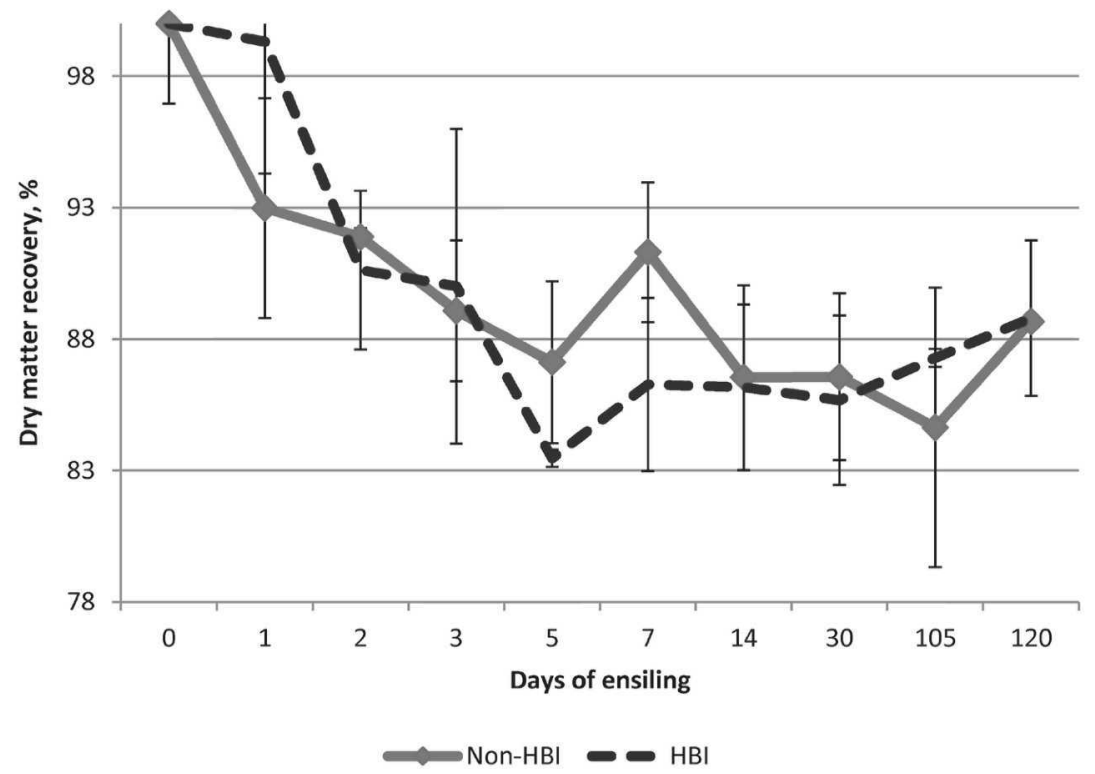

Figure 4. Effect of inoculation or not on the dry matter recovery of triticale ensiled in glass jar mini-silos during $123 \mathrm{~d}$ in Experiment \#1. Interaction of treatment $\mathrm{x}$ day of fermentation $\mathrm{P}<0.22$.

a rapid $\mathrm{pH}$ decline and not necessarily a low final $\mathrm{pH}$ is essential for high quality silage.

Adesogan and Newman (2014) stated that due to continued plant respiration, plant enzymes and aerobic bacteria cause nutrient losses by degrading plant proteins, converting sugars into carbon dioxide and water, and generating heat. The heat generated increases the silage temperature by 8 to $11^{\circ} \mathrm{C}$ or more, depending on the amount of air available. The mini-silos of the present study were vacuumed sealed; therefore, there was little oxygen in the system. Silages temperatures increased less than 4 and $<2^{\circ} \mathrm{C}$ for non-inoculated and inoculated, respectively. Inoculated silage was cooler than the Non-HBI at all time points after $3 \mathrm{~d}$ of fermentation with the exception of $\mathrm{d} 14$ post-ensiling (Figure 3).

The DMR was not affected by either treatment or treatment $\mathrm{x}$ length of fermentation interaction. This result is not surprising, since the theoretical increase in DM recovery by use of an inoculant is probably on the order of one percentage unit based on the difference in fermentation end products and assuming that the inoculant does in fact dominate the fermentation (Muck, 1988). 


\section{Experiment \# 2}

\section{Nutritional content}

Ensiling increased $(\mathrm{P}<0.05)$ the moisture content of the silages relative to the pre-ensiled wilted forage and there were no differences ( $P>0.05$ ) among the four silages (Table 2). The silage resulting from the Non-HBI/PVC treatment had a lower $(\mathrm{P}<0.05) \mathrm{CP}$ than the Wilted/ HBI forage, the difference just short of one full percentage unit (16.60 vs. $17.57 \%$ ). According to Muck (1988), the activity of plant proteases during ensiling of herbage is affected by four main factors: $\mathrm{pH}$, temperature, DM content of the herbage, and time elapsed during fermentation. The DM content, length of ensiling time and temperature were similar among the triticale silages. Thus, the lower CP content of the Non-HBI/PVC silage might have been due to the high $\mathrm{pH}$ observed. Ensiling increased $(\mathrm{P}<0.05)$ EE content with no differences among silages. Chow et al. (2004) observed an increase in total fatty acids in ryegrass due to ensiling. Alves et al. (2011) reported increases in EE levels due to ensiling ryegrass or corn and that inoculation had no effect on these changes. The mechanism by which ensiling increases EE content has not been entirely elucidated, but it may simply be a consequence of DM loss and subsequent concentration of EE (Alves et al., $2011)$ or could involve microbial synthesis. Ensiling increased $(\mathrm{P}<0.05)$ the content of $\mathrm{NH}_{3}-\mathrm{N}$, with the highest values found in the Non-HBI/ PVC silage and the lowest in the HBI/GJ silage. Both, inoculation and the type of mini-silo, had an effect on $\mathrm{NH}_{3}-\mathrm{N}$ of silages, which differs from the results of Davies et al. (1998) that after $90 \mathrm{~d}$ of ensiling of perennial ryegrass, with a sugar content similar to that of the triticale ensiled in the current study, there were no differences in $\mathrm{NH}_{3}-\mathrm{N}$ due to inoculation. Ensiling increased $(\mathrm{P}<0.05)$ the contents of $\mathrm{ADF}$ and lignin over the wilted forages; however, the silages did not differ $(\mathrm{P}>0.05)$ among themselves. The content of aNDF was lowest $(\mathrm{P}<0.05)$ for the Wilted/HBI forage while the other wilted forages and silages presented no differences ( $\mathrm{P}>0.05)$ among them. By contrast, Hunt et al. (1993) determined that ensiling whole plant corn decreased the content of NDF but not ADF and that inoculation had no effects on these fibrous fractions. The differences in results of the two experiments are likely due to the type of crop used for ensiling. Ensiling consumed all the sugars present in the wilted triticale resulting in silages with no sugar content. Merry et al. (2006) ensiled ryegrass forages differing in sugar content (24.4 vs. $12.6 \%$ ) and found that 65 to 75 percent of the sugar had disappeared after $90 \mathrm{~d}$ of fermentation. The levels of sugar observed in that study were two- to four-fold greater than the level of sugar in the present triticale wilted forage. Ensiling also decreased 
TABLE 2.-Nutritional characteristics of pre-ensiled triticale with or without inoculation and of silage made from these forages in two types of mini-silos. ${ }^{1}$

\begin{tabular}{|c|c|c|c|c|c|c|c|c|}
\hline \multirow[b]{2}{*}{ Item $^{2}$} & \multicolumn{2}{|c|}{ Pre-ensiled forages } & \multicolumn{4}{|c|}{ Silage } & \multirow[b]{2}{*}{$\mathrm{SD}$} & \multirow[b]{2}{*}{$P<$} \\
\hline & $\begin{array}{c}\text { Wilted/Non- } \\
\text { HBI }\end{array}$ & $\begin{array}{l}\text { Wilted } \\
\text { /HBI }\end{array}$ & $\begin{array}{l}\text { Non-HBI } \\
\text { /PVC }\end{array}$ & $\begin{array}{l}\mathrm{HBI} \\
/ \mathrm{PVC}\end{array}$ & $\begin{array}{c}\text { Non-HBI } \\
/ \text { GJ }\end{array}$ & $\begin{array}{l}\mathrm{HBI} \\
/ \mathrm{GJ}\end{array}$ & & \\
\hline $\mathrm{DM}^{3}, \%$ & $34.69 \mathrm{a}^{4}$ & $35.38 \mathrm{a}$ & $31.33 \mathrm{~b}$ & $31.85 \mathrm{~b}$ & $31.97 \mathrm{~b}$ & $31.79 \mathrm{~b}$ & 0.59 & 0.0001 \\
\hline $\mathrm{CP}, \%$ & 16.88 & $17.57 \mathrm{a}$ & $16.60 \mathrm{~b}$ & 17.14 & 16.86 & 16.70 & 0.38 & 0.0296 \\
\hline $\mathrm{ADICP}, \%$ & 0.59 & 0.57 & 0.68 & 0.62 & 0.57 & 0.56 & 0.05 & 0.0884 \\
\hline $\mathrm{EE}, \%$ & $2.55 \mathrm{~b}$ & $2.60 \mathrm{~b}$ & $4.01 \mathrm{a}$ & $4.03 \mathrm{a}$ & $4.04 \mathrm{a}$ & $4.00 \mathrm{a}$ & 0.08 & 0.0001 \\
\hline $\mathrm{NH}_{3}-\mathrm{N}, \% \mathrm{CP}$ & $0.03 \mathrm{~b}$ & $0.03 \mathrm{~b}$ & $0.29 \mathrm{c}$ & $0.27 \mathrm{ac}$ & $0.28 \mathrm{ac}$ & $0.25 \mathrm{a}$ & 0.01 & 0.0001 \\
\hline $\mathrm{ADF}, \%$ & $35.00 \mathrm{~b}$ & $33.84 \mathrm{~b}$ & $38.74 \mathrm{a}$ & $37.61 \mathrm{a}$ & $37.81 \mathrm{a}$ & $37.86 \mathrm{a}$ & 0.49 & 0.0001 \\
\hline aNDF, $\%$ & $56.2 \mathrm{a}$ & $54.41 \mathrm{~b}$ & $56.62 \mathrm{a}$ & $55.74 \mathrm{a}$ & $56.51 \mathrm{a}$ & $55.92 \mathrm{a}$ & 0.47 & 0.0001 \\
\hline aNDFom, $\%$ & 52.03 & 51.15 & 51.82 & 51.03 & 52.21 & 50.90 & 0.81 & 0.2003 \\
\hline Lignin, \% & $0.65 \mathrm{~b}$ & $0.76 \mathrm{~b}$ & $3.02 \mathrm{a}$ & $2.56 \mathrm{a}$ & $2.48 \mathrm{a}$ & $2.42 \mathrm{a}$ & 0.56 & 0.0001 \\
\hline Starch, \% & 0 & 0 & 0.30 & 0.56 & 0.39 & 0.27 & 0.33 & 0.1854 \\
\hline Sugar, \% & $4.66 \mathrm{a}$ & $5.72 \mathrm{a}$ & $0 \mathrm{~b}$ & $0 \mathrm{~b}$ & $0 \mathrm{~b}$ & $0 \mathrm{~b}$ & 0.47 & 0.0001 \\
\hline $\mathrm{NFC}, \%$ & $15.23 \mathrm{a}$ & $17.24 \mathrm{a}$ & $8.78 \mathrm{~b}$ & $9.24 \mathrm{~b}$ & $8.43 \mathrm{~b}$ & $9.04 \mathrm{~b}$ & 1.15 & 0.0001 \\
\hline Ash, \% & $12.01 \mathrm{~b}$ & $11.08 \mathrm{~b}$ & $14.73 \mathrm{a}$ & $14.66 \mathrm{a}$ & $14.81 \mathrm{a}$ & $15.26 \mathrm{a}$ & 0.83 & 0.0001 \\
\hline
\end{tabular}

${ }^{1}$ Homolactic bacteria inoculation (HBI), PVC mini-silos (PVC), glass jars mini-silos (GJ)

${ }^{2}$ Dry matter (DM), crude protein (CP), acid detergent insoluble crude protein (ADICP), ether extract (EE), acid detergent fiber (ADF), neutral detergent fiber (aNDF), water soluble carbohydrates (WSC), and non-fibrous carbohydrates (NFC)

${ }^{3}$ As fed, all others DM basis

${ }^{4}$ Within a row, means with different letters differ $\mathrm{P}<0.05$ 
$(\mathrm{P}<0.05)$ the content of NFC with no differences $(\mathrm{P}>0.05)$ among the four silages. Ensiling had the opposite effect $(\mathrm{P}<0.05)$ on the content of ash but the silages did not differ $(\mathrm{P}<0.05)$ from each other. Neither ensiling nor inoculation affected ( $P>0.05$ ) the contents of ADICP, aNDFom or starch. Thus, there was little difference in nutritional characteristics between silages made in PVC mini-silos containing $2,000 \mathrm{~g}$ of forage and GJ mini-silos containing $300 \mathrm{~g}$ of forage. Consequently, the GJ mini-silos are deemed adequate for use as a model to study the effects of ensiling on silage nutritional content of the forage. Inoculation did not affect the nutritional composition of these silages.

\section{Fermentation characteristics}

Ensiling increased $(\mathrm{P}<0.05)$ the content of lactic acid, acetic acid, propionic acid, ethanol, total VFA and $\mathrm{NH}_{3}-\mathrm{N}$ over the levels present in the pre-ensiled, wilted forage (Table 3). This is the result of the conversion of simple plant sugars to organic acids, especially lactic and acetic, during the anaerobic fermentation (Rooke and Hatfield, 2003). The highest level $(\mathrm{P}<0.05)$ of lactic acid and total VFAs was detected in the HBI/PVC silage surpassing the other silages, which did not differ $(\mathrm{P}>0.05)$ from one another. The intended function of $\mathrm{HBI}$ is to promote efficient utilization of a crop's WSC, resulting in intensive and rapid lactic acidification (Weinberg and Muck, 1996). Therefore, it appears that the HBI used in the present study performed as expected in the PVC mini-silo but not in the GJ mini-silo. The highest contents of acetic acid and $\mathrm{NH}_{3}-\mathrm{N}$ were found in the Non-HBI/PVC silage, which differed $(\mathrm{P}<0.05)$ from the HBI/GJ silage with the lowest contents. Muck (1988) stated that for the successful ensiling of forages $(<50 \% \mathrm{DM})$, compared to making hay $(>75 \% \mathrm{DM})$, decreasing silage $\mathrm{pH}$ rapidly and maintaining low silage temperature are the most appropriate means of reducing proteolysis. The fact that the lowest level of silage $\mathrm{NH}_{3}-\mathrm{N}$ resulted from the HBI/GJ treatment and that silage temperature remained below ambient temperature, constitute evidence that the HBI used in the current study fostered rapid acidification, thus preserving the true protein fraction. Silage $\mathrm{pH}$ was lowest for the HBI/PVC treatment, which differed $(\mathrm{P}<0.05)$ from the Non-HBI silages ensiled either in PVC or GJ, but not $(\mathrm{P}>0.05)$ from the HBI/GJ treatment. The use of HBI, especially in PVC mini-silos, resulted in accelerated production of lactic acid and decreased $\mathrm{pH}$. Forage in GJ silos containing $300 \mathrm{~g}$ net weight ensiled well, however the amount of material ensiled may have been too small to detect differences due to inoculation in terms of lactic acid content and $\mathrm{pH}$. Xiccato et al. (1994) found that $2 \mathrm{~L}$ experimental silos are useful devices to study the conservation of ensiled forages. This is at least twice the volume of the GJ used herein. Johnson et al. 
TABLE 3.-Fermentation characteristics of pre-ensiled triticale with or without inoculation and of silage made from these forages in two types of mini-silos. ${ }^{t}$

\begin{tabular}{|c|c|c|c|c|c|c|c|c|}
\hline \multirow[b]{2}{*}{ Item } & \multicolumn{2}{|c|}{ Pre-ensiled forage } & \multirow[b]{2}{*}{$\begin{array}{c}\text { Non- } \\
\text { HBI/PVC }\end{array}$} & \multicolumn{3}{|c|}{ Silage } & \multirow[b]{2}{*}{ SD } & \multirow[b]{2}{*}{$\mathrm{P}<$} \\
\hline & $\begin{array}{c}\text { Wilted/Non- } \\
\text { HBI }\end{array}$ & Wilted/HBI & & $\mathrm{HBI} / \mathrm{PVC}$ & Non-HBI/GJ & $\mathrm{HBI} / \mathrm{GJ}$ & & \\
\hline $\mathrm{pH}$ & $6.37 \mathrm{a}^{2}$ & $6.37 \mathrm{a}$ & $5.07 \mathrm{~b}$ & $4.87 \mathrm{~d}$ & $4.97 \mathrm{c}$ & $4.92 \mathrm{~cd}$ & 0.04 & 0.0001 \\
\hline \multicolumn{9}{|c|}{ Fermentation profile $^{3}(\%)$} \\
\hline Lactic acid & $0.23 \mathrm{c}$ & $0.24 \mathrm{c}$ & $3.71 \mathrm{~b}$ & $5.33 \mathrm{a}$ & $4.43 \mathrm{~b}$ & $4.51 \mathrm{~b}$ & 0.31 & 0.0001 \\
\hline Acetic acid, & $0.19 \mathrm{c}$ & $0.20 \mathrm{c}$ & $4.20 \mathrm{a}$ & $3.56 \mathrm{ab}$ & $3.54 \mathrm{ab}$ & $3.47 \mathrm{~b}$ & 0.27 & 0.0001 \\
\hline Propionic acid & $0.19 \mathrm{~b}$ & $0.21 \mathrm{~b}$ & $0.28 \mathrm{a}$ & $0.29 \mathrm{a}$ & $0.28 \mathrm{a}$ & $0.26 \mathrm{a}$ & 0.02 & 0.0001 \\
\hline Butyric acid & $\mathrm{ND}^{4}$ & $\mathrm{ND}$ & $\mathrm{ND}$ & $\mathrm{ND}$ & ND & ND & & \\
\hline Ethanol & $0 \mathrm{~b}$ & $0 \mathrm{~b}$ & $0.98 a$ & $0.87 \mathrm{a}$ & $0.88 \mathrm{a}$ & $0.76 \mathrm{a}$ & 0.11 & 0.0001 \\
\hline Total VFA & $0.61 \mathrm{c}$ & $0.66 \mathrm{c}$ & $8.18 \mathrm{~b}$ & $9.90 \mathrm{a}$ & $8.24 \mathrm{~b}$ & $8.20 \mathrm{~b}$ & 0.31 & 0.0001 \\
\hline $\mathrm{NH}_{3}-\mathrm{N}, \mathrm{CP}$ equivalent & $0.18 \mathrm{c}$ & $0.20 \mathrm{c}$ & $1.83 \mathrm{a}$ & $1.70 \mathrm{ab}$ & $1.73 \mathrm{ab}$ & $1.53 \mathrm{~b}$ & 0.09 & 0.0001 \\
\hline
\end{tabular}


(2005) concluded that red clover in $170 \mathrm{ml}$ glass mini-silos handpacked to contain approximately $105 \mathrm{~g}$ net weight or in vacuum sealed plastic bags containing $100 \mathrm{~g}$ of forage, fermented well and permitted detection of differences due to inoculation; however, these authors failed to report the results when perennial ryegrass was ensiled using the same methodology. Cherney et al. (2004) concluded that when it is not practical to evaluate all treatments using commercial silos, vacuum-sealed plastic bags could be used to ensile corn, with samples as small as 200 $\mathrm{g}$ to assess treatment differences. Thus, it appears that forages that possess greater density than triticale (i.e. lower NDF content) may be ensiled in amounts as small as $100 \mathrm{~g}$ and still allow for the detection of treatment differences. An important detail is that the studies of Xiccato et al. (1994) and Johnson et al. (2005) were of short fermentation length $(<45 \mathrm{~d})$ compared to the present study in which fermentation lasted $123 \mathrm{~d}$. Differences in the duration of the ensiling period may explain some of the differences in results among studies. To our knowledge, this is the first time that PVC mini-silos and GJ were compared. However, the type of mini-silo (PVC vs. GJ) and the amount of forage ensiled (2,000 vs. $300 \mathrm{~g})$ per mini-silo are confounded. In order to determine the separate effects of these two factors, a trial should be conducted comparing mini-silos of each material (PVC or GJ) of similar volume.

\section{NDF digestion characteristics}

Ensiling triticale decreased $(\mathrm{P}<0.05) 30 \mathrm{~h}$ NDF digestibility (Table 4) for Non-HBI/PVC and HBI/GJ silages relative to the pre-ensiled wilted forages. The present NDF digestibility of the four silages (54 to 57.5 percent) exceed those reported by Emile et al. (2007), of in vivo NDF digestibility for six cultivars of triticale that ranged from 44 to 55 percent (mean of $49.8 \%$ ). The lower digestibility of those silages may be explained by their higher lignin content ( 8.7 vs. $2.6 \%$ ). Emile et al. (2007) obtained evidence that genotype influences the digestibility of NDF in triticale. The lowest NDF digestibility recorded in the present study was that of Non-HBI/PVC silage, which differed $(\mathrm{P}<0.05)$ from HBI/PVC, the silage of greatest digestibility; but these PVC silages did not differ $(P>0.05)$ from those ensiled in the GJ. Inoculation did not improve the digestibility of NDF when triticale was ensiled in GJ; furthermore, the HBI/GJ silage had a lower numerical value than the Non-HBI/GJ silage. This anomaly confirms the assertion of Weinberg and Muck (1996) that inoculation may have variable effects on fiber digestibility. Undigested NDF (uNDF) is the fibrous fraction that influences physical effectiveness, i.e. gut fill, and digestion/passage dynamics of forages (Paulson, 2014). The term uNDF240 denotes 
TABLE 4.-Neutral detergent fiber (NDF) digestion characteristics of pre-ensiled triticale with or without inoculation and of silage made from these forages in two types of mini-silos. ${ }^{1}$

\begin{tabular}{|c|c|c|c|c|c|c|c|c|}
\hline \multirow[b]{2}{*}{ Item $^{2}$} & \multicolumn{2}{|c|}{ Pre-ensiled forage } & \multirow[b]{2}{*}{$\begin{array}{c}\text { Non-HBI } \\
\text { /PVC }\end{array}$} & \multicolumn{3}{|c|}{ Silage } & \multirow[b]{2}{*}{$\mathrm{SD}$} & \multirow[b]{2}{*}{$\mathrm{P}<$} \\
\hline & $\begin{array}{c}\text { Wilted/ } \\
\text { Non-HBI }\end{array}$ & Wilted/HBI & & $\mathrm{HBI} / \mathrm{PVC}$ & $\begin{array}{c}\text { Non-HBI } \\
/ \text { GJ }\end{array}$ & HBI/GJ & & \\
\hline $30 \mathrm{~h}$ digestibility, \% of NDF & $58.19 \mathrm{a}^{3}$ & $60.73 \mathrm{a}$ & $54.11 \mathrm{c}$ & $57.52 \mathrm{abc}$ & $57.35 \mathrm{abc}$ & $55.95 \mathrm{bc}$ & 1.34 & 0.0001 \\
\hline uNDF $240, \%$ of NDF & $8.78 \mathrm{~b}$ & $8.12 \mathrm{~b}$ & $13.03 \mathrm{a}$ & $11.95 \mathrm{a}$ & $12.16 \mathrm{a}$ & $12.32 \mathrm{a}$ & 0.47 & 0.0001 \\
\hline TTNDFD, $\%$ of NDF & $53.25 \mathrm{a}$ & $55.31 \mathrm{a}$ & $46.14 \mathrm{~b}$ & $47.50 \mathrm{~b}$ & $47.70 \mathrm{~b}$ & $46.94 \mathrm{~b}$ & 0.97 & 0.0001 \\
\hline $\mathrm{NDFD}_{\mathrm{kd}}, \% / \mathrm{h}$ & 4.27 & 4.48 & 4.20 & 4.25 & 4.22 & 4.14 & 0.14 & 0.0615 \\
\hline
\end{tabular}

${ }^{1} \mathrm{H}$ omolactic bacteria inoculation (HBI), PVC mini-silos (PVC), glass jars mini-silos (GJ)

${ }^{2}$ Neutral detergent fiber (NDF), non-degradable NDF after $240 \mathrm{~h}$ (uNDF240), total tract NDF digestion (TTNDFD) and rate of NDF digestion (NDF $\mathrm{F}_{\mathrm{kd}}$ ) ${ }^{3}$ Within a row, means with different letters differ $\mathrm{P}<0.05$ 
the uNDF determined at a specific time of fermentation. The TTNDFD assay is different from other fiber quality measures because it is a direct quantitative predictor of fiber digestion (Combs, 2015). Ensiling increased $(\mathrm{P}<0.05) \mathrm{uNDF} 240$ and decreased $(<0.05)$ TTNDFD, but the silages did not differ $(\mathrm{P}>0.05)$ among one another. A reported average TTNDFD value for grasses is $47 \pm 8 \%$ (Combs, 2015) and the present silages fell well within this range. Results of the present trial suggest that TTNDFD is not as sensitive in detecting treatment differences as $30 \mathrm{~h}$ NDF digestibility. There was no treatment effect $(P>0.05)$ for $\mathrm{NDF}_{\mathbf{k d}}$. Thus, the variability in $30 \mathrm{~h}$ NDF digestibility among the silages may not be explained by either change in uNDF240 or the rate of NDF digestion.

\section{Aerobic Stability}

Aerobic metabolism is the cause of silage deterioration when it is exposed to $\mathrm{O}_{2}$ (Rooke and Hatfield, 2003). Upon exposing silages to air, microorganisms oxidize organic acids and other substrates (e.g. sugars and starches) causing heating and decreased nutritive value. The changes that may occur during the period of aerobic exposure (feed out) are as important as those of initial phases of ensiling in terms of preserving nutrients and maintaining the hygienic quality of the silage prior to consumption by the animals (Wilkinson and Davies, 2012). The use of temperature is a simple and reliable criterion to determine aerobic stability as an additional parameter of silage quality (Honig, 1986). Treatment did not affect $(\mathrm{P}>0.12)$ the temperature of the silages during the $168 \mathrm{~h}$ of aerobic exposure; the averages observed were $20.2^{\circ} \mathrm{C}$ for Non-HBI/GJ, $17.6^{\circ} \mathrm{C}$ for $\mathrm{HBI} / \mathrm{GJ}, 18.6^{\circ} \mathrm{C}$ for Non-HBI/PVC and $18.8^{\circ} \mathrm{C}$ for HBI/PVC. All of the silages remained stable throughout the period of aerobic exposure (Figure 5). A target for silage aerobic stability has been set at $7 \mathrm{~d}$ including time in the feed through (Wilkinson and Davies, 2012). This target was met in the present study. In contrast, Weinberg et al. (2010) observed that the temperature of silages made from wilted wheat (inoculated and non-inoculated) registered a large increase after $72 \mathrm{~h}$ of aerobic exposure. Ozduven et al. (2010) concluded that inoculation even had a detrimental effect on the aerobic stability of triticale silage. However, Demirci et al. (2011) found that HBI did not affect the aerobic stability of a mixture of triticale and vetch silage relative to non-HBI silage. A plausible explanation for the high aerobic stability of the silages in the present study is the very low content of starch and lack of sugar (Table 2) offering aerobic microbes little substrate, in addition to appreciable levels of acetic acid (Table 3), which inhibited the development of spoilage organisms.

As for future work using small mini-silos $(<1 \mathrm{~L})$, several lengths of fermentation period should be included since differences due to treat- 


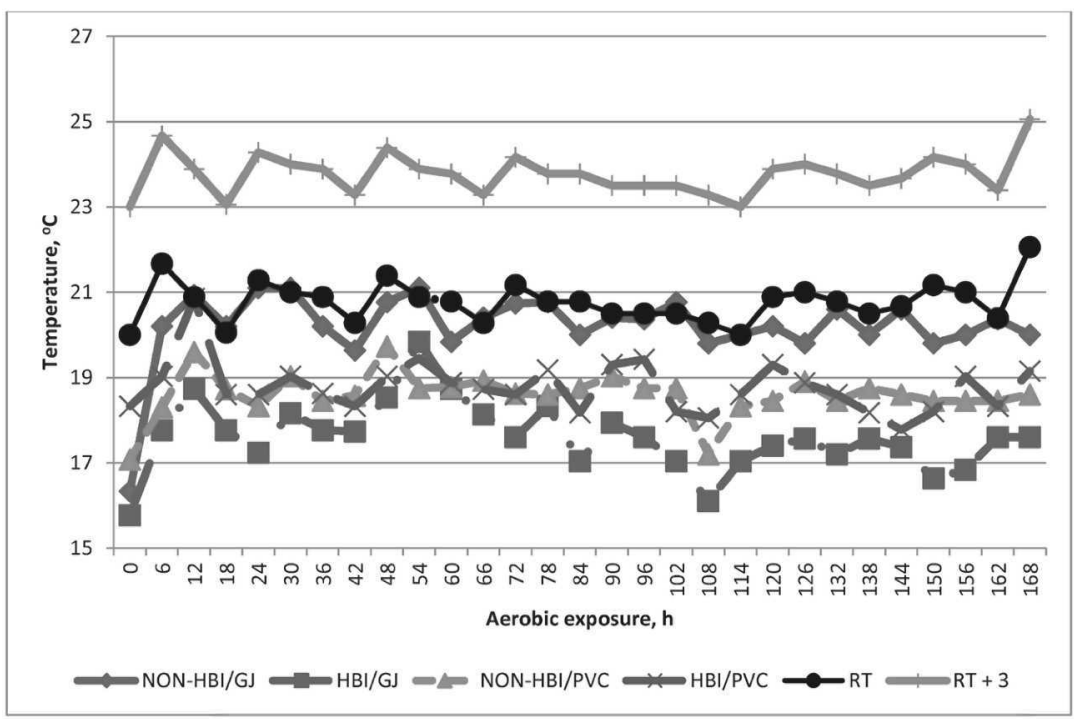

FIGURE 5. Effects of inoculation and type of silo on triticale silage temperature during $168 \mathrm{~h}$ of aerobic exposure. Interaction treatment $\mathrm{xh}$ of aerobic exposure $=P>0.32$. $\mathrm{RT}=$ room temperature; $\mathrm{RT}+3=$ room temperature $+3^{\circ} \mathrm{C}$.

ments are most active during the first two weeks and may not be detectable after prolonged fermentation ( $>120 \mathrm{~d}$ ). In addition, ensiling of crops that are less bulky (i.e. lower NDF content) with a higher density than triticale (e.g. high moisture corn) would allow for a greater mass of material to be ensiled in each $0.946 \mathrm{~L}$ mini-silo and possibly promote differentiation by treatment.

\section{CONCLUSIONS}

In Experiment \#1, inoculation decreased average $\mathrm{pH}$ and temperature of the silage when mini-silos were opened after different lengths of fermentation, but had no effect on DMR. In Experiment \# 2, there was little difference in the nutritional content of silages made using PVC or GJ mini-silos. The HBI/PVC treatment yielded silage with the highest content of lactic acid and $30 \mathrm{~h} \mathrm{NDF}$ digestibility and the lowest $\mathrm{pH}$ and acetic acid levels. There were no differences due to inoculation of silage stored in the GJ mini-silos in fermentation profile or fiber digestibility. All treatments resulted in silage of high aerobic stability. The $300 \mathrm{~g}$ of wilted forage ensiled in the GJ may have been too little to detect differences due to inoculation after $123 \mathrm{~d}$ of fermentation. 


\section{LITERATURE CITED}

Adesogan, A. T. and Y. C. Newman, 2014. Silage Harvesting, Storing, and Feeding. SSAGR-177. Agronomy Department, UF/TFAS Extension. 7 pp.

Alves, S. P., A. R. J. Cabrita, E. Jerónimo, R. J. B. Bessa and A. J. M. Fonseca, 2011. Effect of ensiling and silage additives on fatty acid composition of ryegrass and corn experimental silages. J. Anim. Sci. 89: 2537-2545.

Cherney, D. J. R., J. H. Cherney and W. J. Cox, 2004. Fermentation characteristics of corn forage ensiled in mini-silos. J. Dairy Sci. 87: 4238-4246.

Chow, T. T., V. Fievez, M. Ensberg, A. Elgersma and S. De Smet, 2004. Fatty acid content, composition and lipolysis during wilting and ensiling of perennial ryegrass (Lolium perenne L.): preliminary findings. Grassland Science in Europe, Vol. 9: 981-983.

Colovic, R., D. Vukmirovic, D. Palic, M. Plavsic, D. Glamocic, I. Jajic and D. Jeremic, 2010. A simple system for studying the fermentation dynamics of silage. J. Proc. Energy Agric. 14 (3): 157-159.

Combs, D., 2015. Forage quality and utilization: total tract NDF digestibility. In: Proc., 2015 Western States Alfalfa and Forage Symposium, Reno, NV, 2-4 December 2015. 5 pp.

Davies, D. R., R. J. Merry, A. P. Williams, E. L. Bakewell, D. K. Leemans and J. K. S. Tweed, 1998. Proteolysis during ensilage of forages varying in soluble sugar content. J Dairy Sci. 81: 444-453.

Demirci, U., N. Gülsen and G. Keles, 2011. Effects of bacterial inoculants on fermentation and aerobic stability of baled triticale-Hungarian vetch silage and lamb performance. Kafkas Univ Vet Fak Derg 17 (2): 297-302.

Emile, J. C., C. C. Jobim, F. Surault and Y. Barriere, 2007. Genetic variations in the digestibility in sheep of selected whole-crop cereals used as silages. Animal 1(8): 1122-1125.

Heinrichs, J. and P. Kononoff, 1996. Evaluating particle size of forages and TMRs using the New Penn State Forage Particle Separator. DAS 02-42.

Honig, H., 1986, Evaluation of aerobic stability. Proc. Eurobac Conference, Uppsala, Sweden. pp 76-82.

Hunt, C. W., W. Kezer, D. D. Hinman, J. J. Combs, J. A. Loesche and T. Moen, 1993. Effects of hybrid and ensiling with and without a microbial inoculant on the nutritional characteristics of whole-plant corn. J. Anim. Sci. 71: 38-43.

Johnson, H. E., R. J. Merry, D. R. Davies, D. B. Kell, M. K. Theodorou and G. W. Griffith, 2005. Vacuum packing: a model system for laboratory-scale silage fermentations. $J$. Appl. Microbiol. 98: 106-113.

McAllister, T. A. and A.N. Hristov, 2000. The fundamentals of making good quality silage. Adv. Dairy Technol. 12: 381-399.

Merry, R. J., M. R. F. Lee, D. R. Davies, R. J. Dewhurst, J. M. Moorby, N. D. Scollan and M. K. Theodorou, 2006. Effects of high-sugar ryegrass silage and mixtures with red clover silage on ruminant digestion. 1 . In vitro and in vivo studies of nitrogen utilization. J. Anim. Sci. 84: 3049-3060.

Muck, R. E., 1988. Factors influencing silage quality and their implications for management. J. Dairy Sci. 71: 2992-3002.

Ozduven, M. L., Z. Kursun Onal and F. Koc, 2010. The effects of bacterial inoculants and/or enzymes on the fermentation, aerobic stability and in vitro dry and organic matter digestibility characteristics of triticale silages. Kafkas Univ Vet Fak Derg 16 (5): 751-756.

Paulson, J., 2014. Applications of uNDF in ration modeling and formulation. Forage Focus Dec. 2 pp.

Rooke, J. A. and R. D. Hatfield, 2003. Biochemistry of ensiling, pp 95-139, In: Silage Science and Technology. Agronomy Monograph No. 42. D. R. Buxton, R. E. Muck and J. H. Harrison (eds) Am. Soc. Agron., Madison, WI.

SAS Institute. 2004. SAS/STAT 9.1. User's Guide: SAS Institute, Inc. Cary, NC 275132414 , USA. 
Weinberg, Z. G. and R. E. Muck, 1996. New trends and opportunities in the development and use of inoculants for silage. FEMS Microbiology Reviews 19: 53-68.

Weinberg, Z. G., P. Khanala, C. Yildiz, Y. Chena and A. Arieli, 2010. Effects of stage of maturity at harvest, wilting and LAB inoculant on aerobic stability of wheat silages. Anim. Feed Sci. Technol. 158: 29-35.

Wilkinson, J. M. and D. R. Davies, 2012. The aerobic stability of silages: key findings and recent developments. Grass Forage Sci. 68: 1-19.

Xiccato, G., M. Cinetto, A. Carazzolo and M. E. Cossu, 1994. The effect of silo type and dry matter content on the maize silage fermentation process and ensiling loss. Anim. Feed Sci. Technol. 49(3-4): 311-323. 
